\title{
Arany, Turgenyev, Áprily és a cica
}

\section{Motívumok hasonlósága, fordítói lelemény, kutatói bizonytalanság}

Arany János (1817-1882) és Ivan Szergejevics Turgenyev (1818-1883) kortársak voltak. Életük hossza megegyezik, születésük és haláluk éve majdnem azonos egymáséval. Nemrég ünnepelhettük mindkettőjük születésének kétszázadik évfordulóját.

Ezek is érdekes hasonlóságok, de egyszerüen tények, nincs okunk csodálkozni rajtuk. A következőkben viszont olyan hasonlóságra szeretném felhívni a figyelmet, amelyet bátrabban mondhatunk meglepőnek. Arany közismert versének, a Családi körnek (1851) és Turgenyev világhírü kisregényének, az Első szerelemnek (1860) egy-egy részlete feltűnően emlékeztet egymásra. Mindkét szövegrészlet az összességében nyugalmat sugárzó, de apró mozgásokkal teli esti kert leírása. A felbukkanó motívumok hasonlóságát a témabeli egyezés persze megmagyarázza, Turgenyev szövegében mégis meglepi az olvasót az Aranytól ismert képek, jelenetek kombinációja. Egy-egy megszokott motívum megjelenése természetesen szót sem érdemelne, de egyszerre három hasonlóságnak az együttállása már figyelmet kelt. Azt persze nem merném mondani, hogy Turgenyev ismerte Arany versét, a fordított irányú hatás pedig már csak a müvek keletkezési ideje miatt is kizárható. Nagyon valószínü, hogy csupán érdekes véletlennel van dolgunk. Mint látni fogjuk, egyezésekröl nem is beszélhetünk.

Abban viszont biztos vagyok, hogy a Turgenyev-kisregény fordítóját, Áprily Lajost erősen befolyásolta az Arany-vers. Nem hinném, hogy akaratlanul került a hatása alá. Inkább arra gondolok, hogy a Turgenyev-szöveg témája és hangulata azonnal felidézte benne az Arany-verset, és fordításának szóválasztásával, megformálásával - feltehetőleg egyszerre tiszteletből és játékból - Arany Jánosra is emlékezni és emlékeztetni kívánt.

A bevezetés lezárásaként olyasmiről is szólnom kell, ami részben magánügy, de a kutatói etika problémájához is tartozik. Bevallom: könnyen lehet, hogy Arany és Turgenyev szövegrészletének hasonlóságára nem elsőként figyeltem fel. Elképzelhetö, hogy egyetemistaként valamelyik oktatómtól hallottam róla, vagy a csoporttársaimmal beszélgetve került szóba. Csaknem negyven év távolából erre már nehéz visszaemlékezni. És természetesen az is lehetséges, hogy az orosz irodalom valamelyik búvára, egy Turgenyev-szakértő írt már arról, amiről az alábbiakban szó lesz. Ha így van, elnézést kérek tőle is, az olvasóktól is.

\section{A vizsgált szövegrészletek}

Ebben a pontban egyrészt az Arany-vers részletét idézem; másrészt Turgenyev szövegrészletét eredetiben, Áprily Lajos fordításában, valamint a sajátomban. Az utóbbival persze nem az a célom, hogy Áprily remekével versenyre keljek, hanem az, hogy egy nyersebb változat bemutatásával segítsem kiemelni Áprily megoldásainak a jellemzőit. 


\section{Családi kör}

Este van, este van: kiki nyúgalomba!

Feketén bólingat az eperfa lombja,

Zúg az éji bogár, nekimegy a falnak,

Nagyot koppan akkor, azután elhallgat.

Mintha lába kelne valamennyi rögnek,

Lomha földi békák szanaszét görögnek,

Csapong a denevér az ereszt sodorván,

Rikoltoz a bagoly csonka, régi tornyán.

Udvaron fehérlik szöre egy tehénnek:

A gazdasszony épen az imént fejé meg;

Csendesen kérődzik, igen jámbor fajta,

Pedig éhes borja nagyokat döf rajta.

Ballag egy cica is - bogarászni restel -

Óvakodva lépked hosszan elnyult testtel,

Meg-megáll, körülnéz: most kapja, hirtelen

Egy iramodással a pitvarba terem.

(http://mek.oszk.hu/00500/00597/html/vs185003.htm\#30)

\section{Тургенев: Первая любовь (XV)}

Особенно поразила меня происшедшая в ней [т. е. в Зинаиде] перемена в один теплый, тихий вечер. Я сидел на низенькой скамеечке под широким кустом бузины; я любил это местечко: оттуда было видно окно Зинаидиной комнаты. Я сидел; над моей головой в потемневшей листве хлопотливо ворошилась маленькая птичка; серая кошка, вытянув спину, осторожно кралась в сад, и первые жуки тяжело гудели в воздухе, еще прозрачном, хотя уже не светлом.

(https://ilibrary.ru/text/1335/p.15/index.html

Интернет Библиотека Алексея Комарова)

\section{Első szerelem (15. fejezet: Áprily Lajos fordításában)}

Ez a változás [ti. Zinaidáé] egyszer különösen meghökkentett - egy csendes, meleg estén. Alacsony kis padon ültem, terebélyes bodzabokor alatt; szerettem ezt a helyet, onnan látni lehetett Zinaida szobájának ablakát. Ott ültem; fejem felett a sötétedő lomb között egy kis madár csapongott; elnyúlt testtel szürke macska osont óvakodva a kertben, az első bogarak mély zúgása hallatszott a még átlátszó, de már fénytelen levegőben.

(Ivan Turgenyev: Első szerelem. Fordította: Áprily Lajos. In: A boszorkány. Három regény. Magyar Könyvklub, Budapest, 1999. 173. [Alapkiadás: Európa Könyvkiadó, 1973, 1984.] || Vö. http://mek.oszk.hu/00500/00511/00511.htm) 


\section{Első szerelem (Saját fordításom)}

Különösen meglepett a benne [ti. Zinaidában] végbement átalakulás egy meleg, csendes estén. Alacsony padocskán ültem egy széles bodzabokor alatt; szerettem ezt a helyecskét: onnan látható volt Zinaida szobájának ablaka. Ültem; a fejem felett a sötétedő lomb között serényen forgolódott egy kis madárka; egy szürke macska, kinyújtva hátát, óvatosan lopakodott a kertbe, és az első bogarak súlyosan búgtak a még áttetsző, bár már nem világos levegőben.

\section{A motívumok}

A két szövegrészletnek három motívumára figyeltem fel, három apró jelenetre. Mindegyikben állat szerepel.

Az egyik a zúgó bogár; Turgenyevnél többes számban. Önmagában, a másik két motívum nélkül nem figyelnénk fel rá, hiszen szokványos, kötelező szereplő az esti kertben. Aranynál a leírás elején jelenik meg, és a koppanásától válik érdekessé. Turgenyevnél a bogarakkal a leírást záró jelenetben találkozunk. Áprily a mély zúgás jelzős szerkezettel adja vissza a hangjukat, az orosz eredetiben a súlyosan búgtak szinesztéziaszerü igei, határozós szintagma áll.

Érdekesebb a csapongó, szárnyas lény: Aranynál denevér, Turgenyevnél viszont madárka. A denevér jelenléte sem meglepő az esti kertben, és persze a madárkáé sem az, bár az utóbbi nem jellegzetesen esti szereplő. Ami igazán figyelmet érdemel, az a csapong ige. Szinte biztos vagyok abban, hogy Áprily a Családi kör hatására választotta. Azért is gondolok erre, mert a mü fordításának a MEK-ben szereplö, szintén Áprilytól való változata a vizsgált szövegrészletet tekintve egyetlen szóban különbözik az általam idézett kiadástól: ott a csapongott helyén a nyugtalankodott igealak szerepel. Ez szó szerint közelebb áll a 'serényen/fáradozva forgolódott' jelentésű orosz eredetihez. Nem tudom megállapítani, hogy Áprily milyen sorrendben alkalmazta a két változatot: először választott Arany hatására, és csak később változtatott a szöveghüség kedvéért, vagy éppen fordítva.

A leginkább ,gyanús” szereplő a cica: nagyon is beleillik az esti kert világába, de nem elengedhetetlen résztvevője (szemben a bogárral). Turgenyev eredeti szövegében a szürke macska a hátát kinyújtva lopakodik; aligha független Aranytól, hogy Áprily ezt az elnyúlt testtel szerkezettel adja vissza. Szinte csodálkozom, hogy a müfordításba macska került, nem pedig cica...

\section{Zárógondolatok}

Cikkem megírására az késztetett, hogy az utóbbi években többször is a kezembe került ifjúkori kedves olvasmányom, Turgenyev remekmüve. Most is elbüvöl egészében és részleteiben egyaránt. A csodálatos részletek közé tartozik az esti kert leírása is, az Arany-párhuzam pedig különösen érdekessé teszi. Szerettem volna ezt az él- 
ményemet megosztani az olvasókkal, a fiatalokat pedig arra biztatni, hogy olvassák Turgenyevet. Az idézett részletet pedig felhasználhatónak gondolom a magyar irodalom oktatásában, voltaképpen minden iskolatípusban. Ha akad olyan tanár, oktató, aki többet tud nálam a „rejtélyes” hasonlóságról, annál jobb.

\author{
Horváth László \\ tudományos munkatárs \\ Nyelvtudományi Intézet \\ https://orcig.org/0000-0003-4522-043X
}

\title{
Mit magyaráz a kollokálódás, és mit nem? A rekkenö hideg példája
}

\section{Bevezetés}

Az írás azzal foglalkozik, hogy milyen tényezők motiválják, milyen tényezők gátolják a rekkenö hideg szerkezet létrejöttét. A rekkenö hideg kifejezés szokatlan, míg a rekkenö höség/meleg megszokott, gyakori. Az innovatív szerkezet létét a Google keresőjével nyert adatok támasztják alá (lásd (1)-(2)). ${ }^{1}$

(1) Rekkenő hideg és szállingózó havazás fogadta a csapatokat a barcelonai teszthét második napján. ${ }^{2}$

(2) Mivel rekkenö hideg volt, megálltunk a stadion felé menet egy vendéglátóipari pultnál, ahol elfogyasztottunk egy-egy pohár forralt - figyelem! - sört. $^{3}$

\section{A hideg és a meleg HőÉRzET nyelvi konceptualizációjáról}

A hőérzet esetében a szélső értékekhez (fagy, dermesztő hideg - hőség, kánikula) erőteljes tapasztalatok kapcsolódnak, így két ellentétes, kontrasztos tartomány különül el. Bár a fagyást a hétköznapi beszédben is megkülönböztetjük a forróság (sugárzás) okozta égéstől (vagy a vegyszer okozta marástól), olyan tapasztalatunk is van, hogy szövetroncsoló hatásuk nagyon is hasonló. A testi tapasztalat hasonlósága alapján, vélhetöleg, nem tartanánk oximoronnak az égetö hideg kifejezést sem. A rekkenö fagy szerkezetet azonban az oximoron példájaként, kreatívan alkotja meg egy fórumozó. ${ }^{4}$

1 A 2018 végén „rekkenő hideg” kifejezésre indított keresésre 100 körüli találatot kaptam, igaz, ezek egy része ismétlődött.

2 Forrás: https://nepszava.hu/1153971_vettel-nyerte-a-masodik-tesztnapot; megtekintés: 2018. 12. 25.

3 Forrás: http://markert.hu/wordpress/?p=2758; megtekintés: 2018. 12. 25.

${ }_{4}$ Internetes oximoronlánc-fórumban (https://tinyurl.com/ya9h4u7k), megtekintés: 2018. 12. 25. 